\title{
IMPLEMENTASI NILAI-NILAI ISLAM DALAM MENINGKATKAN KUALITAS PELAYANAN PADA PELANGGAN PENDIDIKAN
}

\author{
Muhammad Amin Nur ${ }^{1}$
}

\begin{abstract}
Currently we are in an era of quality, every consumer or customer of both goods and services expect quality. Institutions that rely on service quality, people will be increasingly in demand as customers. Instead institution that ignores its customers quality service will be abandoned. Customer education is always to be aware of the needs and expectations include the students and their parents who feel the direct impact of education services. One indicator of the low quality of education is the low level of trust and the level of customer satisfaction (learners and their parents) to educational services. The low quality of educational services to customers often happens because the pengalola institutions ignore the universal values that the values of Islam.

Now it's time especially educational institutions of Islamic education institutions to review their Islamic values and implement them in improving the quality of service to its customers, in order to remain prosperous Islamic educational institutions and competitive in the global competition intensifies.
\end{abstract}

Keywords: Islamic Values, Quality Service, Customer Education

\section{A. Pendahuluan.}

Siap atau tidak, suka atau tidak, saat ini setiap perusahaan, lembaga atau organisasi apapun tanpa terkecuali organisasi/lembaga pendidikan pada semua jenjang dan satuan pendidikan berada dalam persaingan yang sangat ketat. Selain karena disebabkan oleh arus globalisasi semakin deras, persaingan muncul karena para pelanggan sudah semakin cerdas, banyak menuntut, serta tersedia berbagai macam produk barang/jasa sebagai alternatif pilihan. Karena itu setiap perusahaan, organisasi atau lembaga termasuk didalamnya lembaga pendidikan berusaha keras dengan berbagai cara untuk merebut "hati" pelanggannya.

1 Dosen Fakultas Ilmu Tarbiyah Dan Keguruan Universitas Islam Negeri Maulana Malik Ibrahim Malang Jl. Gajayana No. 50 Malang 65144 
Oleh karena itu fokus dari manajemen pendidikan saat ini menurut Yoyon Bahtiar dan Prihatin (2010;327) mengalami perubahan dari sekedar melayani proses pendidikan menjadi bagaimana membuat pemakai pendidikan diubah menjadi pelanggan pendidikan (customer pendidikan), agar pelanggan pendidikan memberikan loyalitas yang tinggi dan tidak berpaling pada lembaga lain.

Seringkali ukuran kesuksesan sebuah lembaga pendidikan dilihat dari banyaknya jumlah santri/siswa/mahasiswa sebagai pelanggan yang menikmati secara langsung layanan jasa pendidikan pada sebuah lembaga pendidikan. Eksistensi dan keberlangsungan sebuah lembaga pendidikan juga seringkali diukur dari seberapa lama lembaga pendidikan tersebut survive mempertahankan layanan jasa pendidikan yang diberikan kepada masyarakat dengan mempertahankan loyalitas pelanggannya baik pelanggan internal seperti para guru dan karyawan maupun pelanggan eksternalnya seperti para peserta didik dan masyarakat sebagai unsur utama pendukungnya.

Pentingnya pelayanan yang berkualitas terhadap pelanggan,karena keberhasilan pelayanan kualitas dapat menimbulkan hal-hal sebagai berikut, yitu:

1. Pelayanan yang berkualitas dapat menyebabkan pelanggan potensial yaitu calon peserta/calon orang tua peserta didik segera mengambil keputusan untuk memilih layanan jasa pendidikan yang ditawarkan oleh lembaga pendidikan.

2. Pelayanan yang berkualitas juga dapat menimbulkan kepercayaan pelanggan terhadap produk layanan jasa pendidikan yang ditawarkan.

3. Pelayanan yang berkualitas dapat mempertahankan para pelanggan (peserta didik dan orang tuanya agat tetap loyal menggunakan layanan jasa pendidikan kita.

4. Pelayanan yang berkualitas dapat mendorong pelanggan lama untuk terus melanjutkan proses pendidikan pada jenjang lebih tinggi ditempat yang sama.

Dengan memberikan pelayanan yang berkualitas pada pelanggan, maka akan menimbulkan adanya kepuasan dikalangan para pelanggan, selanjutnya akan melahirkan loyalitas pelanggan. Ada beberapa alasan penting yang mengharuskan lembaga pendidikan untuk selalu berusaha 
mempertahankan loyalitas pelanggannya antara lain, yaitu:

1. Dengan memiliki pelanggan yang loyal dalam hal ini para guru dan peserta didik yang loyal maka akan mempengaruhi kualitas pembelajaran.

2. Pelanggan yang loyal akan menjadi pendukung utama penyelenggaraan pendidikan, karena mereka akan menjadi donatur atau mencari donasi untuk mendukung pembiayaan lembaga pendidikan dimana mereka mengenyam pendidikan ketika mereka telah menjadi alumni dan menjadi orang yang sukses secara finansial.

3. Pelanggan yang loyal juga akan membantu untuk mempromosikan keberadaan dan kemajuan lembaga pendidikan secara ketok tular (world of mauth) ke calon pelanggan potensial sehingga aktivitas ini mengurangi biaya promosi.

Buchori Alma (2003;173) mengutip pendapat Kotler, Hayes dan Bloom (2002) menyebutkan ada enam alasan mengapa lembaga harus menjaga dan mempertahankan pelanggannya, yaitu:

1. Pelanggan yang sudah ada, prospeknya dalam memberi keuntungan cenderung lebih besar.

2. Biaya menjaga dan mempertahankan pelanggan yang sudah ada, jauh lebih kecil daripada biaya mencari pelanggan baru.

3. Pelanggan yang sudah percaya pada suatu lembaga dalam satu urusan/bisnis yang lain. Misalnya lembaga pendidikan yang sudah diyakini sebagai lembaga yang baik dalam bidang teknologi, juga dipercaya akan diminati orang bila mengadakan kursus atau membuka jurusan baru dalam bidang bahasa atau olah raga.

4. Jika pada suatu perusahaan banyak langganan lama, akan memperoleh keuntungan karena adanya peningkatan efisiensi. Langganan lama pasti tidak akan banyak lagi tuntutan, perusahaan cukup menjaga dan mempertahankan mereka. Untuk melayani mereka bisa digunakan karyawan-karyawan baru dalam rangka melatih mereka, sehingga biaya pelayanan lebih murah. Tentu karyawan yunior ini telah diberi pengarahan lebih dulu, agar tidak berbuat sesuatu yang mengecewakan pelanggan. 
5. Pelanggan lama ini tentu telah banyak pengalaman positif berhubungan dengan perusahaan, sehingga mengurangi biaya psikologis dan sosialisasi.

6. Pelanggan lama akan selalu membela perusahaan, dan berusaha pula menarik/memberi refernsi teman-teman lain dan lingkungannya untuk mencoba berhubungan dengan perusahaan.

Berdasarkan alasan-alasan tersebut diatas jelaslah bagi kita bahwa memberikan pelayanan yang berkualitas pada pelanggan pendidikan merupakan sebuah keharusan karena dengan pelayanan yang berkualitas, maka pelanggan pendidikan akan merasa puas dan mereka akan loyal dalam memanfaatkan layanan jasa pendidikan yang diberikan pada mereka, sehingga memberikan keuntungan yang besar pada lembaga pendidikan. Lalu siapa pelanggan pendidikan itu? Dan bagaimana memberikan layanan yang berkualitas pada mereka? Serta bagaimana peran nilai-nilai islam dalam memberikan pelayanan yang berkualitas tersebut? Berikut ulasannya.

\section{B. Pelanggan Pendidikan}

Wijaya (2012;45) mengutip pendapat Schauherman dkk (1994) mengartikan pelanggan sebagai seseorang yang menerima produk atau jasa kita. Mereka adalah orang yang memiliki kebutuhan mutu yang harus dipuaskan untuk mencapai keberhasilan. Sementara menurut Davies dan Ellison (2003), pelanggan juga dapat disebut sebagai para pemangku kepentingan yang terdiri atas dua macam, yaitu:

1. Pemangku kepentingan internal (Internal Steakholder), yaitu kelompok dalam lembaga pendidikan yang meliputi siswa dan orang tua siswa, pemerintah, karyawansekolah (guru dan karyawan pendukung), pengunjung sekolah secara teratur. Pada kategori ini, ada berbagai subkategori, yaitu siswa menurut umur, karyawan menurut pengalaman kerja, pemerintah menurut bidang kepentingan atau pengaruh serta pengunjung sekolah menurut afiliasi dan tujuan.

2. Pemangku kepentingan eksternal (eksternal steakholder), yaitu individu dan kelompok di balik sistem pendidikan, yang meliputi calon siswa, calon orang tua siswa, calon karyawan, alumni, sekolah lain, masyarakat lokal, kalangan industri dan perdagangan, birokrat pendidikan lokal, kantor standar kualitas pendidikan, 
lembaga pelatihan guru, departemen pendidikan dan organisasi nasional.

Untuk lebih jelasnya dapat dilihat pada matrik berikut ini.

\begin{tabular}{|c|c|c|}
\hline & $\begin{array}{l}\text { Pelanggan Internal } \\
\text { Orang yang bekerja } \\
\text { di dalam sistem dan } \\
\text { dipengaruhi oleh } \\
\text { sekolah }\end{array}$ & $\begin{array}{l}\text { Pelanggan Eksternal } \\
\text { Orang yang } \\
\text { mempengaruhi sekolah, } \\
\text { tetapi berada diluar } \\
\text { sistem }\end{array}$ \\
\hline $\begin{array}{l}\text { Pelanggan Langsung } \\
\text { Orang yang } \\
\text { menggunakan sistem }\end{array}$ & $\begin{array}{l}\text { - Siswa } \\
\text { - Guru } \\
\end{array}$ & 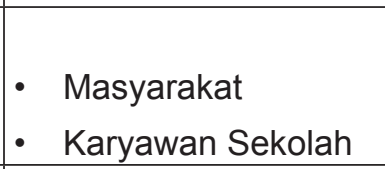 \\
\hline $\begin{array}{l}\text { Pelanggan tidak } \\
\text { langsung } \\
\text { Orang yang } \\
\text { membutuhkan } \\
\text { orang lain untuk } \\
\text { menggunakan sistem }\end{array}$ & 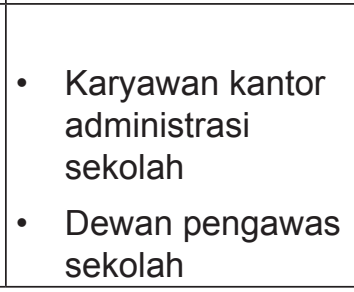 & - $\begin{array}{l}\text { - } \\
\text { - }\end{array}$ \\
\hline
\end{tabular}

(diadaptasi dari David Wijaya 2012;47)

Lembaga pendidikan perlu melakukan analisis pelanggan mereka dengan tujuan untuk mengetahui keinginan dan harapan mereka. Untuk mengetahui keinginan orang tua siswa misalnya, lembaga pendidikan bisa melakukan wawancara, FGD (Forum Group Discustion), kuesioner, tujuan utamanya adalah memenuhi kebutuhan siswa/peserta didik. Oleh karena itu lembaga pendidikan perlu mengidentifikasi kebutuhan siswa secara jelas.

\section{Tipe-Tipe Pelanggan}

Hermawan Kertajaya (2003:100) dalam Ratih (2010;134) membagi tahapan loyalitas pelanggan kedalam lima tingkatan mulai dari terrorist customer sampai advocator customer, lebih jelasnya tingkatan tersebut adalah sebagai berikut:

1. TerorristCuctomer, adalah pelanggan yang suka menjelek-jelekkan merek perusahaan dikarenakan tidak suka atau pernah tidak puas dengan layanan yang diberikan perusahaan. Pelanggan seperti ini bersikap teroris yang suka menyusahkan perusahaan. 
2. Transactional Customer, yaitu pelanggan yang memiliki hubungan dengan perusahaan yang sifatnya sebatas transaksi, pelanggan seperti ini membeli satu atau dua kali, sesudah itu dia tidak mengulangi pembeliannya, atau apabila melakukan pembelian sifatnya kadang-kadang. Pelanggan yang memiliki sifat seperti ini mudah dating dan pergi karena tidak memiliki relationship yang baik dengan produk/merek perusahaan, basis relationship-nya adalah transaksional.

3. Relationship Customer, dimana tipe pelanggan ini nilai ekuitasnya lebih tinggi dibandingkan dua jenis pelanggan di atas, pelanggan jenis ini telah melakukan repeat buying dan pola hungannya dengan produk atau merek perusahaan adalah relasional.

4. Loyal Customer, pelanggan jenis ini tidak hanya melakukan repeat buying, tapi lebih jauh lagi sangat loyal dengan produk dan merek perusahaan. Bila ada orang lain yang menjelekkan perusahaan, pelanggan ini tetap bertahan, dia tetap bersama perusahaan seburuk apapun orang menjelekkan perusahaan.

5. Advocator Customer, jenis pelanggan yang terakhir adalah Advocator Customer, pelanggan dengan tingkatan tertinggi, pelanggan semacam ini sangat istimewa dan excellent, mereka menjadi asset terbesar perusahaan bila perusahaan memilikinya. Advocator Customer adalah pelanggan yang suka membela produk dan merek perusahaan, pelanggan yang menjadi juru bicara yang baik kepada pelanggan lain dan pelanggan yang marah apabila orang lain menjelek-jelekkan merek perusahaan.

Dalam konteks pendidikan pelanggan seperti tipe-tipeyang disebutkan di atas juga ada, tidak jarang ada peserta didik atau orang tua peserta didik yang menjelek-jelekkan lembaga pendidikan dimana anaknya belajar, namun ada juga orang uta yang sangat loyal terhadap lembaga pendidikan semua anaknya di lembaga pendidikan yang sama.

\section{Peningkatan Kualitas Pelayanan Sebagai Upaya Membangun Loyalitas Pelanggan Pendidikan}

\section{Makna pelayanan yang berkualitas}

Bisnis lembaga pendidikan adalah bisnis jasa yang sangat menekankan pada aspek pelayanan. Bisnis lembaga pendidikan akan 
diminati oleh masyarakat jika pelayanannya berkualitas, sebaliknya jika pelayanannya tidak berkualitas maka akan ditinggalkan oleh masyarakat sebagai pelanggannya.

Pelayanan yang berkualitas adalah kemampuan maksimum seseorang melakukan sentuhan kemanusiaan dalam melayani atau berhubungan dengan orang lain. Pelayanan yang berkualitas juga dapat berarti upaya maksimum yang mampu diberikan oleh lembaga pendidikan dalam rangka memenuhi kebutuhan pelanggan untuk mencapai suatu tingkat kepuasan tertentu, serta memberikan pelayanan terbaik kepada para pelanggan dengan tujuan untuk membangun loyalitas pelanggan dan meraih ridho Allah.

Adapun Tujuanpelayananyang berkualitas.

1. Untuk menimbulkan kepercayaan dan kepuasan kepada pelanggan

2. Untukmenjaga agar pelanggan merasa dipentingkan dan diperhatikan

3. Untuk mempertahan kan pelanggan agar tetap setia menggunakan layanan jasa yang ditawarkan.

Ada beberapa elemen sesuatu dikatakan berkualitas. Menurut Ciptono (2009) yang dikutip oleh (Umiarso, 2010:123), elemen tersebut yaitu: pertama, kualitas meliputi usaha memenuhi atau melebihi harapan pelanggan. Kedua, Kualitas mencakup produk, jasa, manusia, proses dan lingkungan. Ketiga, Kualitas merupakan kondisi yang selalu berubah (apa yang dianggap berkualitas hari ini mungkin dianggap kurang berkualitas pada saat yang lain). Keempat, kualitas merupakan suatu kondisi dinamis yang berhubungan dengan produk, jasa, manusia, proses dan lingkungan yang memenuhi atau melebihi harapan.

\section{E. Pelayanan yang perlu ditingkatkan kualiatasnya dalam lembaga pendidikan.}

Ada beberapa aspek yang perlu ditingkatkan kualitas dalam memberikan pelayanan pada pelanggan pendidikan, yaitu:

1. Memberikan pelayanan kurikuler yang berkualitas, yaitu: menyediakan pengajar yang kompeten, cara pengajaran yang berkualitas, memberikan materi pengajaran yang berkualitas, memberikan materi ujian yang sesuai yang diajarkan, 
2. Menyediakan sarana dan prasarana pendidikan yang kualitas. Yang termasuk aspek ini adalah; menyediakan infrastruktur pembelajaran yang berkualitas dan memadai, menjamin kapasitas infrastruktur terpenuhi sesuai kebutuhan, kualitas peralatan pembelajaran yang dapat memenuhi kebutuhan, kapasitas pembelajaran tersedia sesuai kebutuhan.

3. Memberikan pelayanan non kurikuler yang berkualitas, yaitu; kualitas layanan administrasi yang cepat, tepat dan sesuai harapan, kualitas layanan perpustakaan memenuhi harapan, kualitas layanan kesejahteraan yang memenuhi harapan.

\section{F. Implementasi Nilai-Nilai Ajaran Islam Dalam Meningkatkan Kualitas Pelayanan Pada PelanganPendidikan}

Konsep pelayanan dalam islam terwujud dalam hubungan antar manusia, karena tidak akan terjadi pelayanan jika tidak terjadi interaksi antara sesama manusia. Dalam lembaga pendidikan terjadi hubungan antar manusia yang memiliki fungsi dan peran yang berbeda-beda. Dalam hubungan/interaksi antar manusia yang ada di lembaga pendidikan terjadi hubungan saling melayani seperti para guru yang melayani peserta didik, para pimpinan dan staff yang melayani kepentingan semua orang yang ada di lembaga pendidikan.

Agar pelayanan dapat terwujud dengan baik dalam hubungan interaksi manusia dalam berbagai aspek dan kepentingan, maka ajaran islam menetapkan beberapa prinsip, yaitu:

1. Prinsip persamaan (Musawah).

Pada hakikatnya setiap manusia sama disisi Allah, perbedaan manusia hanya terletak pada derajat ketaqwaan masing-masing orang terhadap Allah, seperti firman Allah Surat Al-Hujarat ayat 13.Artinya:

"Hai manusia, Sesungguhnya kami menciptakan kamu dariseorang laki-

laki dan seorang perempuan dan menjadikan kamu berbangsa - bangsa dan bersuku-suku supaya kamu saling kenal-mengenal. Sesungguhnya orang yang paling mulia diantara kamu disisi Allah ialah orang yang paling taqwa diantara kamu. Sesungguhnya Allah Maha mengetahui lagi Maha Mengenal". (QS.Alhujarat: 13)

Prinsip persamaan ini penting karena merupakan dasar dalam mengatur hubungan antara manusia. Dengan demikian jika terdapat 
perbedaan didalam suatu organisasi hal itu adalah sebagai akibat dari adanya pembagian kerja atau tugas saja.

Nilai dan sikap ini harusnya senantiasa dihayati oleh para pengelola lembaga pendidikan dan para guru dalam memberikan layanan kepada para peserta didik agar dalam memberikan pelayanan tidak membedabedakan orang yang dilayaninya karena status sosial, kekayaan suku dan lain sebagainya.

2. Prinsip persaudaraan (Ukhuwah).

Semua Muslim bersaudara, prinsip ini dengan sendirinya mengatasi adanya perbedaan bangsa, ras, suku dan status sosial. Seperti firmanAllah dalam Surat Al-Hujarat ayat 10.Artinya:

"Orang-orang beriman itu Sesungguhnya bersaudara.sebab itu damaikanlah (perbaikilah hubungan) antara kedua saudaramu itu dan takutlah terhadap Allah, supaya kamu mendapat rahmat"(QS. Al-Hujarat: 10)

Jadi sekalipun berbeda status sosial masing-masing manusia, prinsip persaudaraan harus dipegang teguh dalam perilaku hidup sehari-hari dan dalam memberikan nilai kepada manusia. Jika prinsip ini selalu dikedepankan dalam proses interaksi maka dapat meminimalisir konflik dan untuk menciptakan kebersamaan dalam sebuah komunitas. Kebersamaan itu penting karena kebersamaan adalah sebuah kekuatan.

3. Prinsip cinta kasih (Mahabbah).

Prinsip ini bersumber dari hadits nabi yang berbunyi :

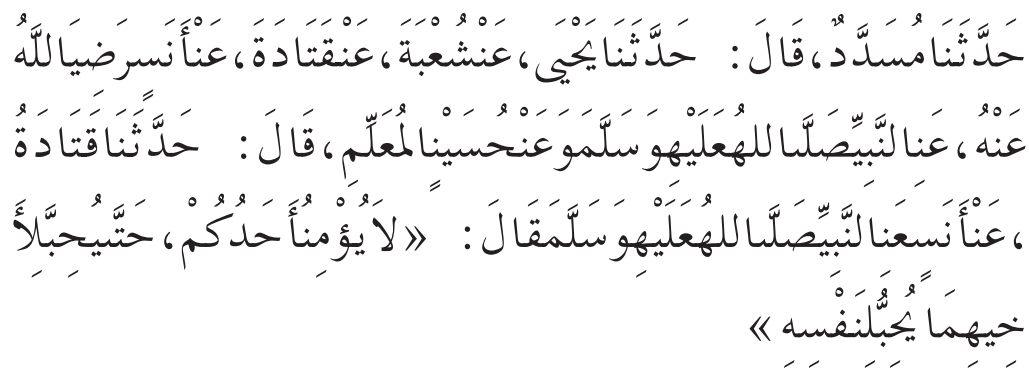

Artinya; tidak sempurna keimanan seseorang hingga mencintai orang lain sebagaimana ia mencintai dirinya sendiri.

Maksudnya ia memperlakukan orang lain sebagaimana ia senang diperlakukan.Manusia diciptakan oleh Allah sebagai makhluk yang paling mulia dan paling sempurna dari pada makhluknya yang lain. Jika 
seseorang melayani orang lain dengan perasaan cinta yaitu mencintai profesi dan mencintai orang lain dengan memberikan pelayanan sesuai dengan profesinya, maka dia akan merasa ringan dalam memberikan pelayanan tersebut. Seperti seorang ibu yang memberikan pelayanan pada anaknya.

4. Prinsip perdamaian atau keselamatan (Silm). Prinsip ini bersumber dari sabda Rasul yang berbunyi :

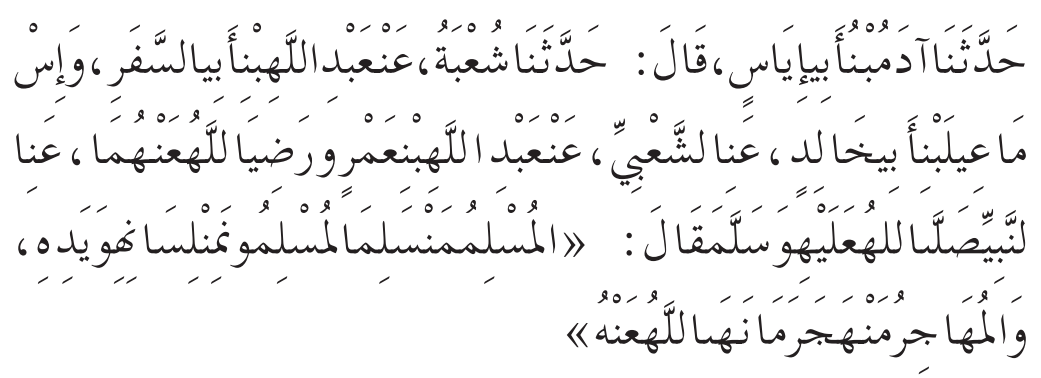

Artinya: seorang muslim adalah orang lain selamat dari gangguan lidah dan tangannya.

Prinsip ini intinya adalah dalam berinteraksi dan memberikan pelayanan pada orang lain seseorang harus dapat menjamin bahwa orang lain akan selamat dari gannguannya baik lisan maupun tangannya sehingga orang lain akan merasakan kedaiaman dalam interaksi.

Dalam konteks pendidikan seorang pendidik ketika memberikan pelayanan pada peserta didiknya dapat menjamin bahwa para peserta didik tidak akan tersakiti baik lisan maupun tangan mereka. Saat proses pembelajaran sejengkel apapun perasaan guru terhadap perilaku peserta didik, dia harus tetap sabar dan ceria dalam menghadapi peserta didik

5. Prinsip tolong-menolong (Ta'awun).

Seorang manusia tidak akan bisa berbuat banyak tanpa ada persatuan dengan manusia yang lain, sehingga benar dalam ilmu sosial yang mengatakan manusia adalah makhluk sosial atau makhluak yang selalu membutuhkan bantuan orang lain dalam menjalankan kehidupannya.

Oleh karena itu tolong;-menolong antar sesama harus tetap terjalin karena merupakan sandaran utama bagi manusia dalam menjalankan kehidupan. Sesuai dengan firman Allahdalam Surat Al-Maidah ayat 2.Artinya: 
"dan tolong -menolonglah kamu dalam (mengerjakan)kebajikan dan takwa , dan jangan tolong -menolong dalam berbuat dosa dan pelanggaran". (QS. Ali-imron:159).

Dalam konteks pendidikan prinsip ini dapat diwujudkan oleh staf administrasi yang bertanggung jwab dan siap memberikan pelayanan dengan cara yang mudah dan cepat guna memenuhi kebutuhan guru dan peserta didik.

6. Prinsip toleransi (Tasamuh).

Seorang muslim harus dapat menerima pendapat orang lain sepanjang orang itu berkata benar. Jadi ukuran toleransi disini adalah kebenaran. Jika pendapat orang lain adalah benar maka seorang muslim harus menerima dan menyetujuinya, sekalipun hal itu datang dari bawahan, Sebagaimana dalam Surat Ali-Imron ayat 159Artinya:

"Maka disebabkan rahmat dari Allah-lah kamu berlaku lemah Lembut terhadap mereka. sekiranya kamu bersikap keras lagi berhati kasar, tentulah mereka menjauhkandiri dari sekelilingmu. Karena itu ma'afkanlah mereka,mohonkanlah ampun bagi mereka, dan bermusyawaratlah dengan mereka dalam urusan itu. Kemudian apabila kamu Telah membulatkan tekad, Maka bertawakkallah kepada Allah. Sesungguhnya Allah menyukai orang -orang yang bertawakkal kepada -Nya ".(QS. Ali-Imron: 159)

Ayat diatas mengajarkan kita untuk selalu bertoleransi, tenggangrasa, bijaksana, menghargai orang lain, dan sanggup menerima pendapat orang lain jika pendapat itu benar

Nilai-nilai normatif di atas akan lebih terasa jika didukung oleh sikap dan nilai islam yang lebih operasional, yaitu:

\section{Sikap ihtimam.}

Sikap ihtimam adalah sikap peduli seseorang terhadap yang lain utamanya pada saudara sesama muslim. Sikap ini diungkapkan oleh Rasul dalam sabdanya:laisa minna manlam yahtam biamril muslimin artinya"bukan dari golongan kami orang yang tidak peduli pada urusan kaum muslimin". Dalam konteks pendidikan hadits ini dapat diimplementasikan oleh pengelola pendidikan yakni para guru dan staff untuk peduli terhadap kebutuhan dan harapan pelanggannya yaitu para siswa dan orang tua siswa. Menurut (Irwan: 2008) Kepedulian guru pada peserta didik dapat diwujudkan dalam tindakan seperti berikut ini:

1. Secara aktif mendengarkan para murid 
2. Melakukan kontak mata dengan para murid

3. Membantu para murid atas pekerjaan rumahnya

4. Menggunakan metode pengajaran yang bervariasi untuk memenuhi kebutuhan-kebutuhan individual setiap muridnya

5. Memberikan penjelasan-penjelasan yang jelas tentang penugasanpenugasan yang diberikan pada para murid

6. Mengecek dengan tujuan untuk memahami kemampuan murid

7. Menyediakan bahan-bahan yang diperlukan para murid

8. Memajang hasil karya para murid

9. Melakukan penyesuaian-penyesuaian jadwal bila diperlukan

10. Memelihara sebuah lingkungan belajar yang aman

11. Menerapkan manajemen kelas secara konsisten

12. Menghabiskan waktu di luar kelas dengan para murid

13. Bekerjasama dengan rekan kerja lainnya

14. Memanggil nama para murid ketika berhubungan dengan mereka

15. Menggunakan gaya komunikasi yang positif

16. Mengungkapkan harapan yang tinggi bagi semua muridnya

17. Meminta pendapat para murid

18. Mengenali para murid secara individual atas prestasinya di dalam maupun di luar kelas.

19. Melakukan komunikasi dengan para orangtua

Dalam ilmu manajemen modern kepedulian ini termasuk salah satu dimensi kualitas yang disebut dengan responsive yaitu sikap yang menunjukkan bagaimana perusahaan/lembaga tanggap terhadap permasalahan pelanggan dan keinginan perusahaan/lembaga membantu dan memberikan solusi dengan cepat dan tepat.

\section{Sikap Rahmah}

Sikap rahmah yaitu sikap sayang dan berempati pada orang lain. Sikap ini diungkapkan oleh rasul dalam sabdanya yang tertera dalam kitab Sunan Turmudzi sebagai berikut: 


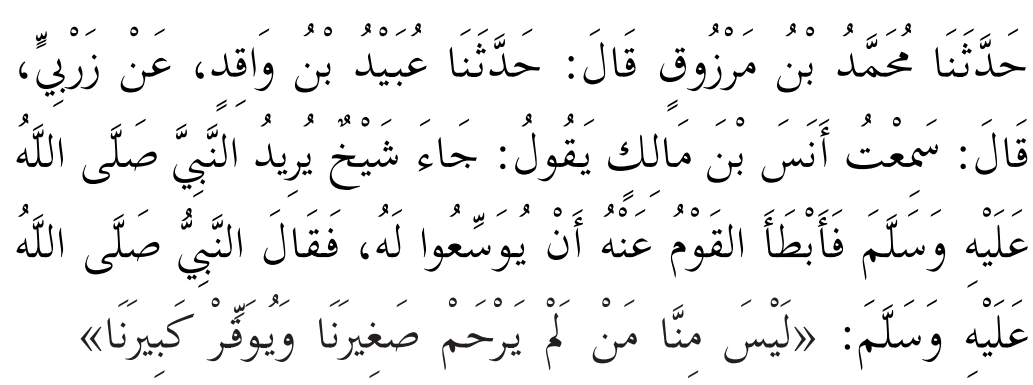

Sikap rahmah/sayang pada peserta didik ketika berada di sekolah dapat diwujudkan dengan sikap positif artinya merasa senang pada mereka, akrab, hormat, rendah hati, sopan santun, empati, bijaksana, tulus ikhlas dalam memberikan pelayanan pada mereka. Tidak bersikap negatif, seperti tinggi hati, meremehkan, egois, tidak bertanggung jawab dan acuh tak acuh pada mereka. Sikap tersebut diatas diwujudkan oleh guru dan staf baik dalam proses pembelajaran maupun di luar proses pembelajaran. Dalam proses pembelajaran para guru tidak hanya memperhatikan sebagaian peserta didik sementara mengabaikan yang lain. Para guru tidak boleh meremehkan pertanyaan peserta didiknya atau mudah menyalahkan peserta didik. Termasuk dalam sikap ini adalah guru perhatian pada kondisi siswa, guru tidak memberikan beban di luar kemampuan siswa.

Dalam ilmu manajemen modern sikap rahmah ini termasuk salah satu dimensi kualitas yang disebut dengan emphaty yaitu.usaha perusahaan/lembaga dalam memberi perhatian serta pengertian terhadap kebutuhan dan keinginan pelanggan. Dalam konteks pendidikan pengelola pendidikan senantiasa menganalisis kebutuhan dan harapan pelanggannya baik pelanggan internal maupun eksternal dan berusaha memenuhi kebutuhan dan harapan tersebut. Agar pengelola lembaga pendidikan dapat memenuhi kebutuhan dan harapan para peserta didik sebagai pelanggan langsung, maka lembaga pendidikan harus memiliki data-data, sebagai mana dikemukakan (davies dan Ellison 2003) berikut ini:

1. Latar belakang sosial budaya peserta didik

2. Potensi peserta didik

3. Tingkat prestasi peserta didik dan kesulitan pembelajaran

4. Strategi pembelajaran yang tepat

5. Prestasi dan pencapaian hasil belajar peserta didik di sekolah setiap 
M. Amin Nur - Implementasi Nilai-nilai Islam ...

hari

6. Persyaratan pendidikan nasional yang terkait dengan kurikulum dan penilaian;

7. Kebutuhan peserta didik di masa mendatang

Berdasarkan data dan informasi tentang peserta didik sebagaimana disebutkan di atas kemudian pengelola lembaga pendidikan melakukan riset tentang kebutuhan dan harapan pelanggannya.

\section{Sikap Itqanul Amal (Profesionalitas).}

Yaitu sikap menekuni perkejaan dengan profesional. Dalam hadits disebutkan Allah sangat mencintai hambanya yang menekuni pekerjaan dengan profesional. Dalam hadits lain disebutkan bahwa jika sebuah pekerjaan ditangani oleh orang yang bukan ahlinya/ tidak profesional maka tunggulah saat kehancurannya.

Implementasi hadit ini dalam kontek pendidikan adalah bahwa untuk memberikan pelayanan yang berkualitas maka para guru dan staff harus bekerja dengan profesional, indikator guru dan staff yang profesional. Adapun indikator guru yang profesional dalam pandangan imam Ibnul Qayyim Al-Jauziyah dalam kitab Al-fikru At-Tarbawi li Ibnil Qayyim Al Jauziyah adalah sebagai berikut:

1. Tidak tenggelam dalam kenikmatan dan kelezatan dunia, karena dunia akan menyihir hati para murabbi.

2. Hendaknya seorang murabbi senantiasa berjihad dengan ilmunya, karena bentuk jihad ini tidak bisa dilakukan kecuali orang sedikit jumlahnya.

3. Memiliki pehaman agama yang mendalam.

4. Mau mendakwahi manusia pada petunjuk cahaya, bersabar dalam meniti jalan dakwah.

5. Tidak mudah memberikan fatwa.

6. Mengetahui kemampuanya, tidak mudah pesimis dengan celaan orang dan tidak mudah terbuai dengan pujian.

7. Hati-hati dalam menjawab pertanyaan yang diajukan padanya.

8. Tidak merasa cukup dengan ilmu yang dimilikinya, ia selalu ingin menambahkan. 
9. Mengamalkan ilmunya.

10. Selalu takut kepada Allah

11. Selalu rindu dan cinta pada ilmu.

12. Senantiasa teratur dalam proses belajar mengajarnya.

Adapun etika seorang Murabbi pada peserta didiknya dalah:

1. Sayang pada mereka dan selalu menghibur mereka dan mengagap murid sebagai anak dan ia sang murabbi adalah bapak/orang tuanya.

2. Selalu memperhatikan peserta didiknya.

3. Tidak hanya sekedar mentransfer ilmu pengetahuan tapi juga mengawasi dan bertanggung jawab terhadap amaliyah perilaku peserta didik.

4. Bersikap adil pada para peserta didik.

5. Mendorong dan membangkitkan semangat peserta didik yang memiliki kemampuan lebih.

6. Sayang pada para peserta namun tidak menghalangi untuk bersikap tegas dalam memberikan hukuman bagi yang melanggar atau melakukan kesalahan.

Sementara guru profesionalsebagaimana dirumuskan oleh PD2TK Direktorat Jenderal Pendidikan Tinggi Departemen Pendidikan Nasional yang dikutip oleh Mulyasa $(2007 ; 20)$ adalah sebagai berikut:

a. Sebagai pendidik, guru yang profesional dalam pekerjaannya berusaha;

1) Mengembangkan potensi/kemampuan dasar peserta didik sebagai pelanggannya, 2). Mengembangkan kepribadian peserta didik, 3) Memberikan keteladanan, 4) Menciptakan suasana pendidikan yang kondusif.

b. Sebagai pengajar, guru yang profesional dalam pekerjaannya, berusaha:

1). Merencanakan pembelajaran, 2) Melaksanakan Pembelajaran yang mendidik, 3). Menilai proses dan hasil pembelajaran.

c. Sebagai pembimbing, guru yang profesional berusaha;1) Mendorong berkembangnya prilaku positif dalam pembelajaran, 2) Membimbing peserta didik memecahkan masalah dalam pembelajaran. 
d. Sebagai pelatih, guru yang profesional berusaha; 1) Melatih keterampilan-keterampilan yang diperlukan dalam pembelajran, 2). Membiasakan peserta didik berprilaku positif dalam pembelajaran.

e. Sebagai pengembang program guru yang profesional berusaha membantu mengembangkan program pendidikan dan sekolah dan hubungan kerjasama intra sekolah.

f. Sebagai pengelola sekolah guru yang profesional berusaha membantu secara aktif dalam menjalin hubungan dan kerjasama antara lembaga pendidikan dengan masyarakat.

g. Sebagai tenaga profesional pendidik ia melakukan upaya-upaya untuk meningkatkan kemampuan profesional.

Adapun indikator staf yang profesional adalah:

Selain tenaga pendidik yang harus profesional dalam pekerjaannya, dalam lembaga pendidikan ada tenaga kependidikan yaitu unsur pimpinan dan karyawan yang harus profesional dalam meningkatkan kualitas pelayanan pada semua orang yang datang di lembaga pendidikan. Mereka itu antara lain adalah cleaning service, security, tenaga administrator lainya. Mereka juga memiliki peran yang sangat besar dalam memberikan pelayanan pada para pelanggan pendidikan. Cleaning service misalnya mereka melayani dalam hal kebersihan kelas, kamar mandi dan toilet, ruang perkantoran, tujuannya adalah untuk menunjang proses pembelajaran dan kenyamanan pelanggan selama berada di lingkungan pendidikan. Sementara security memberikan rasa aman terhadap lingkungan lembaga pendidikan dan menjamin keamanan barang bawaan para pelanggan.

Dalam kitab "kaifa yuaddil muwazzaf al-amanah" Abdul Muhsin menjelaskan bahwa diantara sifat profesional karyawan/pekerja adalah:

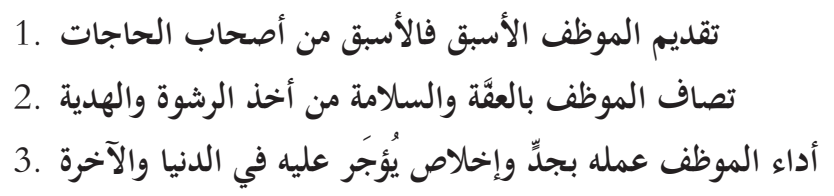

1. Seorang pegawai/pekerja hendaknya memberikan pelayanan terlebih dahulu pada orang yang pertama kali datang padanya demikian seterusnya.

2. Seorang pegawai/pekerja hendaknya memiliki sifat Iffah bersih tidak 
terima suap dan hadiah.

3. Seorang pegawai/pekerja hendaknya mengerjakan pekerjaannya dengan sungguh-sungguh dan ikhlas karena dia yakin bahwa pekerjaan tersebut akan diberi ganjaran di dunia dan akherat.

Apabila guru dan staf di lembaga pendidikan dapat memenuhi beberapa kriteria yang disebutkan di atas, maka dapat memberikan pelayanan yang berkualitas pada peserta didiknya.

\section{At-taharatu wal jamaal (kebersihan dan keindahan penampilan fisik)}

Islam sangat perhatian pada penampilan fisik baik manusia maupun benda. Kepedualian terhadap penampilan fisik diwujudkan pada kebersihan dan keindahan.Islam sangat menganjurkan untuk hidup bersih, bersih batin dan bersih dhohir. Dalam Al-Qur'an Allah SWT

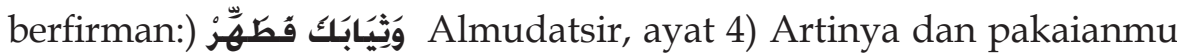
bersihkanlah.

Dan Rasulullah SAW bersabda:

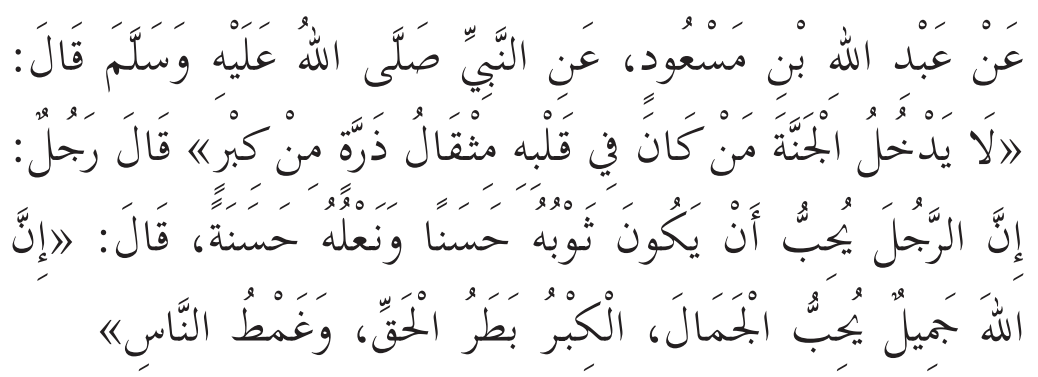

Untuk peningkatan pelayanan pada pelanggan pendidikan maka para guru dan staf harus betul-betul perhatian pada masalah penampilan fisik, kebersihan badan dan keindahan benda-benda yang ada di lembaga pendidikannya. Selayaknya lembaga pendidikan menerapkan 6R yaitu Ringkas, Rapi, Resik, Rawat, Rajin, Ramah. Yang termasuk lingkungan fisik dalam lembaga pendidikan yang selayaknya bersih meliputi exterior dan interior. Yang termasuk exterior adalah lapangan parkir, rambu-rambu yang ada di kampus, taman, kebun-kebun yang asri terpelihara kebersihannya. Adapun yang termasuk interior adalah tata ruang, perabot, peralatan, ventilasi, sirkulasi udara/AC. Disampin itu ada juga tampilan-lain yang selalu mengundang perhatian orang 
yaitu alat-alat tulis, logo, barang cetakan, kop surat, amplop, map ijazah, buku pedoman, pakaian seragam dan lain sebagainya.

\section{Al-wafaa'u bil 'ahdi(Memenuhi janji)}

Dalam hubungan sosial islam sangat menganjurkan setiap orang menepati janji jika ia berjanji, bahkan pengingkaran terhadap janji merupakan salah satu indikator kemunikafikan. Hal ini disebabkan karena dampak dari ingkar janji akan memberikan kekecewaan pada yang lain.

Nilai ajaran islam ini dapat implementasikan pada pelanggan pendidikan oleh para guru dan staf di lembaga pendidikan. Apabila seorang guru pernah berjanji akan memberikan reward pada peserta didiknya maka dia harus menunaikan janjinya tersebut. Apabila seorang guru tidak menunaikan janjinya maka dia akan kehilangan kepercayaan dihadapan peserta didiknya dan hal ini akan mengurangi loyalitas pelangganya peserta didiknya serta dapat merusak citra diri dan lembaganya. Demikian pula para staff yang pernah berjanji dengan para orang tua siswa untuk melakukan pertemuan atau telah melakukan sebuah komitmen bersama maka harus menunaikan janji tersebut, jika tidak maka akan mengurangi pula tingkat kepercayaan dan kepuasan pelanggan terhadap pelanyanan mereka sehingga akan mengurangi tingkatkan kepuasan pelanggan yang akan berakibat pada penurunan tingkat loyalitas pelanggan pada lembaga pendidikan.

Dalam konsep Total Quality Management sikap ini diwujudkan dalam hal pengelola atau pihak manajemen tidak boleh menjanjikan sesuatu yang diluar ekpektasi pelanggan atau menjanjikan sesuatu yang sulit diwujudkan.

\section{G. Kesimpulan}

1. Eksistensi dan kemajuan lembaga pendidikan sangat bergantung pada loyalitas pelanggan utamanya loyalitas guru dan para peserta didik.

2. Loyalitas pelanggan pendidikan akan terwujud jika pengelola pendidikan beserta para guru terus meningkatkan kualitas pelayanannya pada para peserta didik yang menerima langsung layanan jasa pendidikan. 
3. Kualitas pelayanan yang harus terus ditingkatkan dalam pengelolaan lembaga pendidikan adalah pelayanan kurikuler seperti kualitas pembelajaran, pelayanan non kurikuler seperti pelayanan administratif, dan kualitas fisik yakni kualitas sarana dan prasarana pendidikan dan pembelajaran.

4. Dalam upaya meningkatkan kualitas pelayanan pada pelanggan pendidikan, para pengelola lembaga pendidikan dalam bersikap dan bertindak melayani para pelanggan pendidikan senantiasa mengedepankan nilai-nilai universal yakni nilai-nilai ajaran islam seperti; nilai-nilai persamaan (musawah), nilai persaudaraan (ukhuwah), nilai cinta kasih (mahabbah), nilai perdamaian (silm), nilai tolong menolong ( $\left(a^{\prime} a w u n\right)$, dan toleran (tasamuh).Prinsip -prinsip ini sebaiknya didukung oleh sikap ihtimam (kepedulian/ responsive), Rahmah (kasih-sayang), At-tathir wal Jamal (bersih dan Indah), Itqon al-Amal (profesionalitas), Al-wafaa'u bil 'ahdi (menepati janji).

5. Nilai-nilai dan sikap islami adalah sprit yang seharusnya menjadi ruh dalam memberikan pelayanan yang berkualitas pada pelanggan pendidikan sehingga mereka memperoleh kepuasan yang akhirnya melahirkan loyalitas pelanggan yang akan memberikan keuntungan yang besar pada semua stekholder lembaga pendidikan.

\section{DAFTAR PUSTAKA}

Abdul Muhsin bin hamdil Ibad, 2004. Kaifa Yuaddil Muwazzaf Al-Amanah, Mesir Darul Hadiitsah.

Alma, Buchari. 2005.PemasaranStratejikJasaPendidikan. Alfabeta. Bandung.

David Wijaya. 2012. Pemasaran Pendidikan, Mengapa Sekolah memerlukan marketing?. Salemba Empat Jakarta

Hasan bin Ali bin Hasan, 1988. Al-Fikru At-Tarbawi inda Ibinil Qayyim, Riyad Daar Al-Hafid Li Annasyir Wa Al-Tauzi'

Muhammad bin Isa, 1975. Sunan Turmudzi. Mesir, Mustafa Albabi Al-halabi 
M. Amin Nur - Implementasi Nilai-nilai Islam ...

Muhammad Bin Ismail Al-Bukhari, 1422. Sohih Bukhari, Daar Turuqunnajat

Mulyasa, 2007. Standar Kompetensi dan Sertifikasi Guru. Bandung, Remaja Rosda Karya

Umiarso dan Imam Ghazali, 2011. Manajemen Mutu Sekolah di Era Otonomi Pendidikan, Ircisod. Yogyakarta

Ratih Hurriyati, 2010.Bauran Pemasaran dan Loyalitas Konsumen, Bandung Alfabeta

Sulaiman bin Ahmad bin Ayyub, tanpa tahun . Almu'jamul Kabir, Maktabah Ibnu Taimiyah, Kairo

Tim Dosen Administrasi Universitas Pendidikan Indonesia, 2010. Manajemen Pendidikan, Bandung Alfabeta.

Vincent Gasperz. 2010. Total Quality Manajemen, Gramedia Pustaka Tama, Jakarta. 